\title{
HUBUNGAN ANTARA STATUS GIZI DAN TINGKAT ASUPAN ZAT GIZI DENGAN SIKLUS MENSTRUASI PADA REMAJA PUTRI DI KECAMATAN KEDUNGBANTENG KABUPATEN BANYUMAS
}

\section{Correlation Between Nutritional Status and Level of Nutrients Intake with Menstrual Cycle Among Adolescent Girls in Distric Kedungbanteng Banyumas}

\author{
Dita Noviyanti $^{1}$, Endo Dardjito ${ }^{2}$, Bambang Hariyadi $^{3}$ \\ ${ }^{1}$ Ilmu Gizi Universitas Jenderal Soedirman \\ ${ }^{2,3}$ Bagian Gizi Masyarakat, Universitas Jenderal Soedirman \\ ditanoviyanti188@yahoo.co.id
}

\begin{abstract}
Menstrual disorders often occur among adolescent girls. Menstrualdisorder due to several factor including nutritional status, age, physical activity, nutrients intake, disease, stress and influence of cigarettes.The objective of this study is to examine the association between nutritional status and level ofnutrients intake with menstrual cycle among aldolescent in Distric Kedungbanteng Banyumas. Research design is analytic observation with cross sectional approach.Sampling technique used purposive sampling and obtained 69 respondent adolescent girls. The technique of data colelection used menstrual cycle questionnaire, antropometric, food recall $2 \times 24$ jam, food picture and food model.There is $40.6 \%$ respondent have an abnormal menstrual cycle. Nutritionalstatus (11.6\%) classified abnormal. Energy intake (91.3\%), carbohydrate $(94.2 \%)$ protein intake $(89.9 \%)$ and fat intake $(85.5 \%)$ classified an abnormal. Based on analysis of Chi-Square test, there is a significant relation between fat intake with menstrual cycle $(p=0.041)$.

Keywords: Nutritional Status, Nutrients Intake, Menstrual Cycle.
\end{abstract}

\begin{abstract}
Abstrak
Gangguan menstruasi sering dialami oleh remaja putri. Gangguan menstruasi dapat diakibatkan berbagai faktor, termasuk status gizi, usia, aktivitas fisik, asupan zat gizi, penyakit, stress, dan pengaruh merokok. Tujuan penelitian ini adalah untuk menguji hubungan antara status gizi dan tingkat asupan zat gizi dengan siklus menstruasi pada remaja putri di Kecamatan Kedungbanteng Banyumas. Desain penelitian adalah analisis observasional dengan pendekatan cross-sectional. Teknik pengambilan sampel menggunakan purposive sampling dan didapatkan 69 responden remaja putri. Teknik pengumpulan data menggunakan kuesioner siklus menstruasi, antropometri, food recall $2 \times 24$ jam, buku foto makanan, dan food model. Terdapat $40.6 \%$ responde yang mengalami siklus menstruasi tidak normal. Status gizi (11.6\%) dikategorikantidak normal. Asupan energi (91.3\%), karbohidrat (94.2\%), asupan protein (89.9\%), dan asupan lemak $(85.5 \%)$ dikategorikan tidak normal. Berdasarkan analisis menggunakan uji Chi-Square, terdapat hubungan signifikan antara asupan lemak dengan siklus menstruasi $(p=0.041)$
\end{abstract}

Kata kunci : Status gizi, Asupan zat gizi, Siklus menstruasi 


\section{PENDAHULUAN}

Gangguan menstruasi sering terjadi dikalangan remaja. Sebanyak $75 \%$ remaja pada tahap akhir mengalami gangguan menstruasi yang tertunda, ketidakteraturan, rasa nyeri serta pendarahan yang mengharuskan mereka untuk menemui dokter. Gangguan menstruasi harus dapat diatasi karena hal tersebut dapat mempengaruhi sistem reproduksi dan dapat mengganggu aktivitas sehari-hari sehingga dapat menurunkan tingkat produktivitas (Ali et al., 2006 dan Mesarini 2013).

Perbedaan siklus menstruasi disebabkan oleh beberapa faktor antara lain status gizi, umur, aktivitas fisik, asupan makanan, penyakit, stres dan pengaruh rokok. Masa pertumbuhan remaja ada kaitannya dengan kebutuhan gizi yang harus terpenuhi. Ketika kebutuhan gizi dapat terpenuhi maka pertumbuhannya akan menjadi optimal. Kurangnya asupan zat gizi mengakibatkan masalah seperti kurang gizi serta anemia. Keadaan kekurangan zat gizi pada seseorang akan berdampak pada penurunan fungsi reproduksi. Selain itu, asupan zat gizi yang tidak seimbang menyebabkan kecukupan zat gizi menjadi tidak baik, hal itu mempengaruhi ketidakteraturan menstruasi pada remaja (Wiknjosastro, 2005).
Menurut penelitian Laili (2013), siklus menstruasi yang tidak normal banyak ditemukan pada remaja putri di pedesaan yang rentang normalnya adalah 21 sampai 35 hari, selain itu berdasarkan penelitian Ali et al. (2011) menemukan hal yang sama, yaitu terdapat perbedaan yang signifikanantara panjang siklus menstruasi pada remaja putri di kota dan di pedesaan, dimana terdapat $85 \%$ remaja putri di pedesaan mengalami siklus menstruasi yang tidak normal.

Menurut Sari dkk. (2016) prevalensi remaja putri di Kedungbanteng mengalami siklus menstruasi yang tidak normal sebesar $50 \%$ dan sebagian besar sebanyak $76 \%$ tingkat asupan protein tergolong kurang. Berdasarkan latar belakang di atas maka peneliti tertarik untuk melakukan penelitian tentang hubungan status gizi dan tingkat asupan zat gizi dengan siklus menstruasi pada remaja putri di Kecamatan Kedungbanteng.

\section{METODE}

Jenis penelitian ini adalah analitik observasional dengan rancangan penelitian cross sectional. Teknik pengambilan sampel yang digunakan adalah purposivesampling. Populasi penelitian iniadalah seluruh remaja putri berumur 15-17 tahun yang berdomisili 
tetap di wilayah Kecamatan

Kedungbanteng dengan sampel sebesar

69 orang. Analisis bivariat menggunakan

ujiChi Square.

\section{HASIL}

\section{Analisis Univariat}

Karakteristik responden ini terdiri dari berat badan, tinggi badan, umur dan usia menarche. a. Berat Badan

Karakteristik berdasarkan berat badan responden memiliki rata-rata $46,6 \mathrm{~kg}$.

b. Tinggi Badan

Karakteristik berdasarkan tinggi badan reponden memiliki nilai ratarata $152,3 \mathrm{~cm}$

c. Umur dan Usia Menarche

Tabel 1 Karakteristik RespondenBerdasarkan Umur dan Usia

\begin{tabular}{cccc}
\hline No & Karakteristik & \multicolumn{2}{c}{ Frekuensi } \\
\hline 1 & Umur & 12 & 17,4 \\
& 15 & 41 & 59,4 \\
& 16 & 16 & 23,2 \\
\hline 17 & 4 & 5,8 \\
& Usiamenarche & & 23,2 \\
& 11 & 16 & 42 \\
& 12 & 29 & 23,2 \\
& 13 & 16 & 5,8 \\
\hline 14 & 4 & \\
& 15 & &
\end{tabular}

Frekuensi berdasarkan umur responden sebagian besar 59,4\% memiliki umur 16 tahun. Karekteristik responden berdasarkan usia menarche paling banyakresponden memiliki usia
13 tahun yaitu sebesar $42 \%$.

d. Siklus Menstruasi dan Status Gizi

Tabel 2 Distribusi FrekuensiSiklus Menstruasi dan StatusGizi

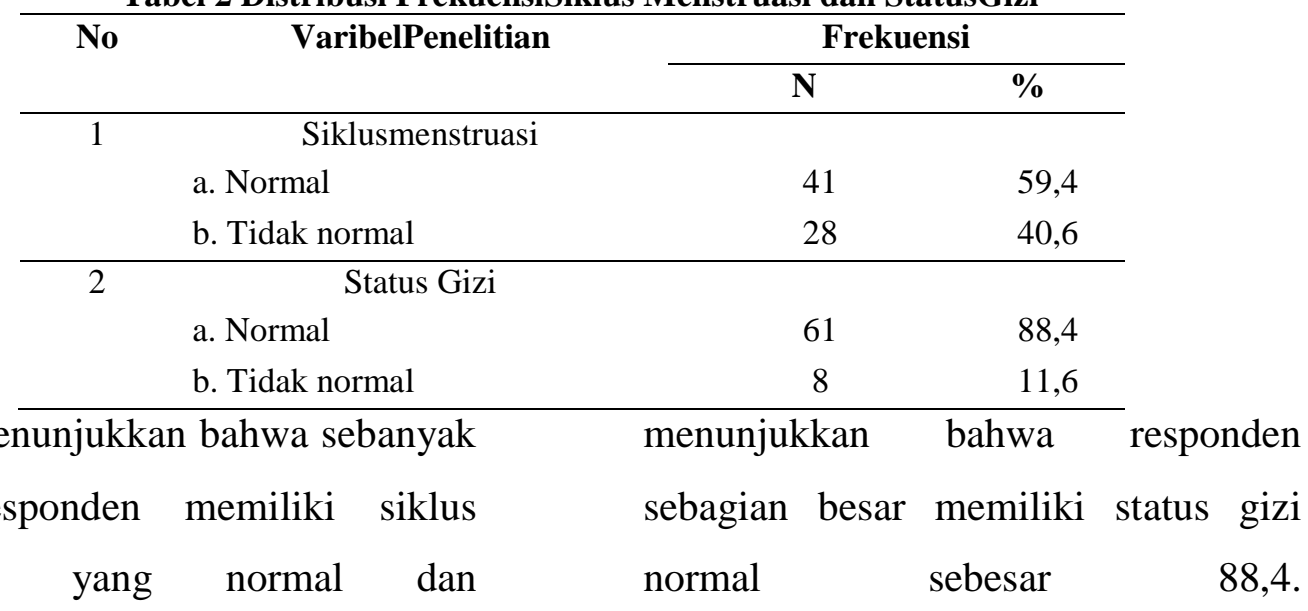


e. Tingkat Asupan Responden

Distribusi frekuensi tingkat asupan responden dapat dilihatpadaTabel 3

berikutini:

Tabel 3 Distribusi FrekuensiTingkat Asupan Responden

\begin{tabular}{|c|c|c|c|c|}
\hline \multirow{2}{*}{ No. } & \multirow{2}{*}{$\begin{array}{l}\text { Tingkat } \\
\text { asupan }\end{array}$} & \multicolumn{2}{|c|}{ Frekuensi } & \multirow[b]{2}{*}{ Rata-rata } \\
\hline & & $\mathrm{N}$ & $\%$ & \\
\hline 1. & 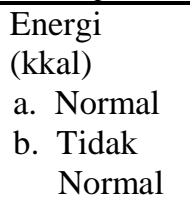 & $\begin{array}{c}6 \\
63\end{array}$ & $\begin{array}{c}8,7 \\
91,3\end{array}$ & $\begin{array}{c}1486,5 \\
66,9 \% \\
\text { dari } \\
\text { AKG }\end{array}$ \\
\hline 2. & $\begin{array}{l}\text { Karbohidrat } \\
\text { (gram) } \\
\text { a. Normal } \\
\text { b. Tidak } \\
\quad \text { normal }\end{array}$ & $\begin{array}{c}4 \\
65\end{array}$ & $\begin{array}{c}5,8 \\
94,2\end{array}$ & $\begin{array}{c}208,9 \\
71,5 \% \\
\text { dari } \\
\text { AKG }\end{array}$ \\
\hline 3. & $\begin{array}{l}\begin{array}{l}\text { Protein } \\
\text { (gram) }\end{array} \\
\text { a. Normal } \\
\text { b. Tidak } \\
\quad \text { normal }\end{array}$ & $\begin{array}{c}7 \\
62\end{array}$ & $\begin{array}{l}10,1 \\
89,9\end{array}$ & $\begin{array}{c}43,95 \\
74,5 \% \\
\text { dari } \\
\text { AKG }\end{array}$ \\
\hline 4. & $\begin{array}{l}\begin{array}{l}\text { Lemak } \\
\text { (gram) }\end{array} \\
\text { a. Normal } \\
\text { b. Tidak } \\
\text { normal }\end{array}$ & $\begin{array}{c}9 \\
60\end{array}$ & $\begin{array}{l}13 \\
87\end{array}$ & $\begin{array}{c}50,4 \\
70,9 \% \\
\text { dari } \\
\mathrm{AKG}\end{array}$ \\
\hline
\end{tabular}

Berdasarkan Tabel 3 sebagian besar responden $91,3 \%$ memiliki asupan energi tidak normal sebanyak 63 responden dengan rata-rata asupan hanya $66,9 \%$ dari nilai AKG. Tingkat asupan karbohidrat sebagian besar responden sebanyak $94,2 \%$ memiliki asupan karbohidrat tidak normal sebanyak 65 orang dengan rata-rata asupan $71,5 \%$ dari AKG. Distribusi frekuensi tingkat asupan protein sebagian besar responden 89,9\% memiliki asupan protein tidak normal sebanyak 62 orang sedangkan untuk distribusi frekuensi tingkat asupan lemak sebagian besar responden $87 \%$ yang memiliki asupan lemak tidak normal sebanyak 60 orang.

\section{Analisis Bivariat}

Analisis bivariat digunakan untuk mengetahui ada atau tidaknya hubungan antara variabel dependen yaitu statusdengan variabel independen dengan menggunakan uji Chi-Square dan uji Fisher Exact. Hasil dari uji tersebuh dapat dilihat pada tabel di bawah ini: 
Tabel 4 Hubungan antara Status Gizi dengan Siklus Menstruasi

\begin{tabular}{|c|c|c|c|c|c|c|c|c|}
\hline \multirow{3}{*}{ No. } & \multirow{3}{*}{ Variabel } & \multicolumn{4}{|c|}{ Siklus menstruasi } & \multirow{2}{*}{\multicolumn{2}{|c|}{ Total }} & \multirow{3}{*}{$\begin{array}{c}\mathrm{P} \\
\text { value }\end{array}$} \\
\hline & & \multicolumn{2}{|c|}{ Normal } & \multicolumn{2}{|c|}{ Tidak normal } & & & \\
\hline & & $\mathrm{n}$ & $\%$ & $\mathrm{n}$ & $\%$ & $\mathrm{~N}$ & $\%$ & \\
\hline \multirow[t]{3}{*}{1.} & Status gizi & & & & & & & \multirow{3}{*}{0.055} \\
\hline & Normal & 39 & 63,9 & 22 & 36,1 & 61 & 100 & \\
\hline & Tidak normal & 2 & 25 & 6 & 75 & 8 & 100 & \\
\hline \multirow[t]{3}{*}{2.} & Tingkat Asupan Energi & & & & & & & \multirow{3}{*}{0.389} \\
\hline & Normal & 5 & 83,3 & 1 & 16,7 & 6 & 100 & \\
\hline & Tidak normal & 36 & 57,1 & 27 & 42,9 & 63 & 100 & \\
\hline \multirow[t]{3}{*}{3.} & $\begin{array}{l}\text { Tingkat Asupan } \\
\text { Karbohidrat }\end{array}$ & & & & & & & \\
\hline & Normal & 4 & 100 & 0 & 0 & 4 & 100 & \multirow{2}{*}{0.141} \\
\hline & Tidak normal & 37 & 56,9 & 28 & 43,1 & 65 & 100 & \\
\hline \multirow[t]{3}{*}{4.} & Tingkat Asupan Protein & & & & & & & \multirow{3}{*}{0.693} \\
\hline & Normal & 5 & 71,4 & 2 & 28,6 & 7 & 100 & \\
\hline & Tidak normal & 36 & 58,1 & 26 & 41,9 & 62 & 100 & \\
\hline \multirow[t]{3}{*}{5.} & Tingkat Asupan Lemak & & & & & & & \multirow{3}{*}{0.041} \\
\hline & Normal & 8 & 88,9 & 1 & 11,1 & 9 & 100 & \\
\hline & Tidak normal & 33 & 55 & 27 & 45 & 60 & 100 & \\
\hline
\end{tabular}

\section{PEMBAHASAN}

\section{Hubungan antara Status Gizi dengan} Siklus Menstruasi

Hasil statistik bivariat penelitian ini menunjukkan tidak ada hubungan antara status gizi denga siklus menstruasi ( $p=0.055)$. Berdasarkan Marmi (2013) menyatakan bahwa status gizi memiliki peranan penting dalam siklus menstruasi. Status gizi yang baik sangat diperlukan untuk menjaga siklus ovulasi dapat terjaga dengan normal. Status gizi yang baik ataupun kurang dapat berpengaruhpada penurunan fungsi hipotalamus yang kemudian tidak akan memberikan rangsangan kepada hipofisis anterior untuk menghasilkan FSH dan LH. Hasil dari penelitian ini tidak sejalan dengan teori di atas. Data yang dihasilkan menunjukkan bahwa tidak ada hubungan antara status gizi dan siklus menstruasi. Menurut teori ketika status gizi normal maka siklus menstruasi juga akan normal. Alasan mengapa hasil dari penelitian ini tidak sejalan karena hal tersebut ada kaitannya dengan usia menarcheresponden yang masih tergolong ke dalam 3 tahun pertama. 
Tidak ada hubungan antara status gizi dengan siklus menstruasi karena responden sebesar $36,1 \%$ yang memiliki status gizi normal dengan siklus menstruasi yang tidak normal. Hasil dari penelitian responden yang memiliki usia menarche 13 tahun sebanyak 42\%.Usia tersebut masih tergolong ke dalam usia 3 tahun pertama sejak menstruasi hal tersebut dapat menyebabkan responden yang berstatus gizi normal mengalami siklus menstruasi yang tidak normal. Menurut Hillard (2002) dan berdasarkan penelitian Bassi et al., (2015) siklus menstruasi pada remaja putri masih tergolong tidak konsisten pada 3 tahun pertama setelah menstruasi. Remaja akan mengalami siklus panjang sehingga siklus menstruasi cenderung akan menjadi tidak teratur, namun dengan bertambahnya usia maka siklus akan lebih menjadi teratur. Siklus yang normal akan terjadi setelah 6 tahun setelah menstruasi pertama sekitar umur 19-20 tahun. Hal tersebut karena pada 3 tahun pertama setelah awal menstruasi remaja putri akan cenderung mengalami anovulasi sehingga menyebabkan siklus menstruasi menjadi panjang.

\section{Hubungan antara Tingkat Asupan}

\section{Energi dengan Siklus Menstruasi}

Hasil uji menyatakan bahwa tidak ada hubungan antara tingkat asupan energi dengan siklus menstruasi ( $p=0.389)$. Tidak ada hubungan antara asupan energi dengan siklus menstruasi karena responden memiliki asupan energi rendah dapat dilihat dari hasil recall $2 \times 24$ jam dibuktikan dari hasil rata-rata asupan energi yang hanya sebesar 1.486,59 kkal. Responden yang memiliki asupan energi tidak normal dengan siklus menstruasi normal sebesar $57,1 \%$.

Hal tersebut karena status gizi sebagian besar 88,4\% responden masih tergolong normal sehingga tidak terjadi suatu keadaan dimana keseimbangan energi menjadi negatif. Jika terjadi keseimbangan negatif, maka berat badan akan kurang dari yang seharusnya (Almatsier, 2009). Kekurangan energi akan menjadikan tubuh mengalami keseimbangan negatif. Hal tersebut akan menyebabkan penurunan sekresi hormon GnRH sehingga terjadi penurunan hormon LH dan FSH yang akan mempengaruhi fungsi reproduksi (Irianto, 2014). Hasil dari peneltian ini sebagian besar responden memiliki status gizi normal, sehingga meskipun asupan energinya kurang responden masih memiliki siklus menstruasi yang normal.

Hubungan antara Tingkat Asupan Karbohidrat dengan Siklus Menstruasi 
Hasil uji Chi-Square di dapatkan nilai $p=0.141$ yang menyatakan bahwa tidak ada hubungan antara asupan karbohidrat dengan siklus menstruasi. Karbohidrat di dalam tubuh terdapat pada sirkulasi darah dalam bentuk glukosa. Karbohidrat sebagai sumber peningkatan energi selama fase luteal berlangsung saat siklus menstruasi. Karbohidrat merupakan sumber peningkatan asupan kalori selama fase luteal sehingga apabila asupan karbohidrat terpenuhi maka tidak akan terjadi pemendekan fase luteal. Hal tersebut berdasarkan Marmi(2013) dan Paath (2005). Hasil dari penelitian ini tidak sejalan dengan teori di atas yang mengatakan bahwa tidak ada hubungan antara asupan karbohidrat dengan siklus menstruasi.

Tidak ada hubungan antara asupan karbohidrat dengan siklus menstruasi karena banyak responden yang memiliki asupan karbohidrat sebesar 56,9\% tidak normal tetapi memiliki siklus menstruasi yang normal. Menurut penelitian Fujirawa et al,. (2007) dan Vuorento (1992)menyatakan bahwa fase luteal pada 3 sampai 4 tahun pertama setelah awal menarche memiliki kecenderungan mengalami gangguan sekresi progesteron yang menyebabkan fase luteal mengalami pemendekan. Hal tersebut lebih banyak ditemukan pada remaja usia 15-17 tahun.
Fase luteal akan menjadi normal seperti kelompok kontrol pada usia 5-6 tahun setelah menarche. Hasil dari penelitian ini usia menarche responden masih tergolong ke dalam 4 tahun pertama yaitu sebesar $23,2 \%$.

Berdasarkan hasil penelitian juga ditemukan bahwa sebagian besar responden berstatus gizi normal. Hasil dari recall 2x24 jam menunjukkan bahwa sebanyak $100 \%$ responden mengonsumsi nasi putih, selain itu tidak ada pembatasan asupan karbohidrat karena responden masih mengonsumsi sumber karbohidrat per harinya lebih dari 100 gram. Oleh sebab itu mereka masih memiliki cadangan karbohidrat untuk digunakan pada siklus menstruasi. Jika kebutuhan karbohidrat tidak mencukupi maka tubuh akan mengubah protein menjadi glukosa melalui glukoneogenesis dalam batas tertentu begitupun dengan lemak yang dapatdijadikan energi ketika asupan karbohidrat tidak terpenuhi (Almatsier, 2009).

\section{Hubungan antara Tingkat Asupan Protein dengan Siklus Menstruasi}

Berdasarkan Hasil uji Chi-Square didapatkan $p=0.693$ yang menyatakan bahwa tidak ada hubungan antara asupan protein dengan siklus menstruasi pada remaja putri. Tidak ada hubungan antara 
asupan protein dengan siklus menstruasi karena responden sebesar 28,6\% yang memiliki asupan protein normal tetapi memiliki gangguan siklus menstruasi. Hal itu karena responden sebagian besar mengonsumsi protein hewani dibandingkan dengan protein nabati. Konsumsi rata-rata jumlahnya 2 porsi sehari yang bersumber dari telur, ikan, ayam dan bakso. Berdasarkan penelitian Jorge et al., (2008) yang dilakukan di Boston membuktikan bahwa tingginya konsumsi protein hewani meningkatkan resiko infertilitas akibat anovulasi ketika seseorang tidak mengalami anovulasi maka tidak akan terjadi siklus menstruasi sedangkan konsumsi protein nabati memiliki efek sebaliknya yaitu dapat mengurangi resiko infertilitas.

Menurut Marmi (2013) dan Paath (2005) Protein merupakan zat gizi yang sangat dibutuhkan oleh tubuh untuk perbaikan sel-sel dalam tubuh. Asupan protein berhubungan dengan panjangnya fase folikuler. Asupan protein hewani yang berlebih akan mempengaruhi dan memperpanjang fase folikuler. Hal tersebut dibuktikan pada penelitian yang dilakukan untuk mengetahui pengaruh diit vegetarian terhadap hormon seks, didapatkan 9 orangvegetarian yang diberikan diit mengandung daging mengalami pemanjangan fase folikuler rata-rata 4,2 hari dan peningkatan $\mathrm{FSH}$ secara signifikan. Sebaliknya 16 orang dengan diit biasa yang beralih ke diit dengan konsumsi daging yang kurang selama dua bulan mengalami peningkatan kadar FH dan pemendekan fase folikuler rata-rata 3,8 hari.

\section{Hubungan antara Tingkat Asupan}

\section{Lemak dengan Siklus Menstruasi}

Hasil uji Chi-Square di dapatkan nilai Fisher Exact sebesar $p=0.041$ yang menyatakan bahwa ada hubungan antara tingkat asupan lemak dengan siklus menstruasi. Berdasarkan hasil penelitian yang telah dilakukan menunjukkan bahwa terdapat $45 \%$ responden yang memiliki asupan lemak tidak normal dengan siklus menstruasi yang tidak normal serta terdapat $88,9 \%$ responden yang memiliki asupan lemak normal dengan siklus menstruasi yang normal. Asupan lemak terendah adalah 21,75 gram dan tertinggi sebesar 110 gram sedangkan rata-rata asupan lemak responden adalah 50,4 gram. Berdasarkan kebutuhan AKG untuk remaja putri usia 15-17 tahun membutuhkan lemak sebesar 71 gram.

Konsumsi lemak akan berpengaruh terhadap persen lemak dalam tubuh yang akan berpengaruh pada peningkatan produksi hormon androsteron yang berfungsi sebagai prekusor selain itu digunakan untuk memproduksi hormon 
esterogen. Proses produksi hormon esterogen terjadi pada sel-sel granulosa dan jaringan lemak. Oleh karena itu, dengan banyaknya jaringan lemak tubuhmaka akan semakin banyak hormon esterogen yang diproduksi dan akan mengganggu keseimbangan hormon reproduksi di dalam tubuh yang pada akhirnya akan mengganggu siklus menstruasi (Baziad 2003 dan Liu 2012). Hasil dari penelitian ini sejalan dengan teori di atas yaitu terdapat hubungan antara asupan lemak dengan siklus menstruasi, ketika seseorang asupannya rendah atau berlebih maka akan berdampak pada siklus menstruasinya.

Ada hubungan antara tingkat asupan lemak dengan siklus menstruasi karena rata-rata asupan lemak responden hanya sebesar $70,9 \%$ dari AKG yang tergolong kurang. Berdasarkan penelitian Fujirawa (2007) menyatakan bahwa pada remaja yang asupan lemaknya rendah akan berdampak pada terganggunya siklus menstruasi, sehingga asupan lemak dengan gangguan siklus menstruasi memiliki hubungan satu sama lain. Hal tersebut sejalan dengan penelitian ini karena hasil yang didapatkan menunjukkan bahwa responden yang memiliki asupan lemak tidak normal mengalami gangguan siklus menstruasi sebesar 45\%. Asupan lemak yang tidak normal didukung dengan data recall yang kecukupannya masih kurang dari nilai $\mathrm{AKG}$.

Menurut Manuaba

(2010)

menyatakan bahwa remaja putri yang mengalami kekurangan asupan lemak akan mengalami penurunan fungsi reproduksi. Hal tersebut karena lemak mempengaruhi kadar hormon gonadotropin dalam urine dan serum, sehingga gonadotropin serta pola sekresinya mengalami penurunan, kejadian tersebut berhubungan dengan fungsi hipotalamus. Ketika kadar hormon gonadrotopin menurun maka FSH,LH, esterogen dan progesteron akan terganggu. Hormon steroid akan mengalami penurunan, LH juga akan menurun hal itu menyebabkan ovarium tidak menghasilkan sel telur yang matang dan mengakibatkan siklus menstruasi menjadi tidak normal.

\section{KESIMPULAN}

Tidak ada hubungan antara status gizi dengan siklus menstruasi. Tidak ada hubungan antara tingkat asupan energi dengan siklus menstruasi. Tidak ada hubungan antara tingkat asupan karbohidrat dengan siklus menstruasi. Tidak ada hubungan antara tingkat asupan protein dengan siklus menstruasi. Ada hubungan antara tingkat asupan lemak dengan siklus menstruasi pada remaja putri di Kecamatan Kedungbanteng Kabupaten Banyumas. 


\section{SARAN}

Remaja putri dianjurkan untuk meningkatkan asupan zat gizi lemak minimal sesuai dengan kebutuhan $\mathrm{AKG}$ agar kecukupan lemak dalam tubuh untuk produksi hormon dapat terpenuhi.

\section{DAFTAR PUSTAKA}

Ali LK, Chen PCY, Lee KK, dan Kaur J., 2006, Menstruation among Aldolescent Girl in Malaysia: a Cross Sectional School Survey, Journal MediaSingapore,47(10) : 468.

Almatsier, S., 2004, Prinsip DasarIlmu Gizi, Jakarta, GramediaPustaka Utama.

Bassi R., Sharma S., Saini A. S. and Kaur M., 2015, Correlation of Menstrual Pattern with Body Mass Index in Young FemaleStudents, Journal ofPhysiology and Pharmacology Advances, 5(2): 556-564.

Baziad, A., 2003, Menopause danAndropause, Edisi 1, Jakarta.

Fujirawa T., Sato N., Awaji H. And Nakata R., 2007, Adverse Effects of Dietary Habits on Menstrual Disorders in Young Women, The Open FoodScience Journal,1: 24-30.

Hillard P, 2002, Menstruation in Young Girls: A

Clinical Perspective, The
AmericanCollege of Obstetricians and
Gynecologists,99(4): 655-662.

Irianto K. 2014. Ilmu KesehatanMasyarakat. Bandung: Alfabet.

Jorge EC, Janet WR, Bernard AR, Walter CW, 2008. Protein Intake and Ovulatory Infertility. AM J Obsetet Gynecol; 198 (2):210e1-210e7.

Liu, Yan., Gold, Ellen Barbara., Lasley, Bill., Johnson, Wesley Oscar. 2013. Factor Affecting Menstrual Cycle Characteristic. American Journal of Epidemiology : 3849.

Manuaba, IBG., 2010. Ilmu Kebidanan, Penyakit Kandungan dan KB untuk Pendidikan Bidan Edisi 2. Jakarta: EGC.

Marmi, S,. 2013, Gizi dalamKesehatan Reproduksi, PustakaPelajar, Yogyakarta.

Mesarini BA dan Astuti VW, 2013, Stres dan Mekanisme Koping terhadap Gangguan Siklus Menstruasi pada Remaja Putri,Jurnal STIKES,6(1):31-42.

Paath EF., 2005, Gizi dalamKesehatan Reproduksi, Jakarta:EGC.

Sari, HP. Dardjito E. dan Anandari D., 2016, Anemia Gizi Besi pada Remaja Putri di Wilayah Kabupaten Banyumas, JurnalKesmas Indonesia,8(1) : 15-33.

Vuorento T, Huhtaniemi I. Daily Levels of Salivary Progesterone During Menstrual Cycle in Adolescent Girls. Fertil Steril 1992;58: 685-90.

Wiknjosastro H., 2006, IlmuKandungan, Jakarta: YayasanBina Pustaka Sarwono Prawirohardjo 